Studia nad Autorytaryzmem i Totalitaryzmem 43, nr 3

Wrocław 2021

https://doi.org/10.19195/2300-7249.43.3.21

\author{
ŁUKASZ GOŹDZIASZEK \\ ORCID: 0000-0003-3843-5037 \\ Uniwersytet Wrocławski \\ lukasz.gozdziaszek@uwr.edu.pl
}

\title{
Ewolucja cywilnych postępowań nakazowych i upominawczych w kierunku respektowania wymogów demokratycznego państwa prawnego
}

\author{
Słowa kluczowe: sąd, nakaz zapłaty, prawo, postępowanie cywilne, postępowanie nakazowe. \\ EVOLUTION OF CIVIL ORDER PROCEEDINGS TOWARDS RESPECTING \\ THE PRINCIPLE OF A DEMOCRATIC STATE RULED BY LAW
}

\begin{abstract}
Although writ proceedings in the Polish civil proceedings have been in operation since the beginning of the modern Polish civil process, there are still controversies in the aspect of fairly structured court proceedings. The defendant may be convinced that their procedural rights have been violated. It is a consequence of considering the case without prior notification of the defendant about the initiation of the proceedings. In such an approach, the judiciary may be perceived as not respecting the standards of a democratic state ruled by law. At the same time, to be closer to the notions of a totalitarian or authoritarian state, because it is not the procedural rights of an individual that are primary, but the effectiveness of the authorities' actions. However, the concerns about the order for payment mechanism are unfounded as long as the model in which the order for payment is applied complies with the necessary requirements. First, the public authority deciding the case should have the attribute of impartiality. It is not necessary that payment orders are issued by a court. However, if the case is not heard by the court, the judicial control of such decisions is necessary. Second, the evidence should not be assessed. The presentation of specific evidence may, however, be a necessary condition for issuing an order for payment. The issue of the public body examining cases is related to the issue of evidentiary proceedings. These two elements define the nature of the order for payment by defining a procedure model. Finally, it should be pointed out that the order mechanism in a democratic state ruled by law should only supplement the examination of cases in ordinary proceedings (or separate proceedings distinguished by the party types). If the number of cases examined in separate proceedings is significant, and even more so if this way of dealing with
\end{abstract}


cases prevails, ordinary proceedings may be merely an illusion. If in a significant number of cases simplified procedures leading to issuing an order for payment are applied, procedural guarantees related only to ordinary proceedings are irrelevant in such cases.

Keywords: court, payment order, law, civil proceedings, writ of payment proceedings.

\section{Wprowadzenie}

Celem artykułu jest ukazanie ewolucji fundamentalnych założeń konstrukcyjnych postępowań nakazowych i upominawczych w prawie polskim oraz określenie kryteriów, których zrealizowanie pozwala uznać mechanizm nakazowy w postępowaniu cywilnym za spełniający standardy demokratycznego państwa prawa. Kluczową w dalszych rozważaniach jest zasada demokratycznego państwa prawnego (art. 2 Konstytucji RP), nie zaś skonkretyzowane wzorce kontroli konstytucyjnej dotyczące bezpośrednio sądu (przykładowo art. 45 lub 176 Konstytucji RP), choć te ostatnie też mają istotne znaczenie dla oceny mechanizmu nakazowego w postępowaniu cywilnym. Jak zostanie wskazane w dalszej części, rozpoznanie sprawy przez sąd nie jest warunkiem koniecznym mechanizmu nakazowego (choć kontrola sądowa jest niezbędna).

Mechanizm nakazowy w postępowaniu cywilnym jest rozwiązaniem mającym długą tradycję. Stosowany był zarówno w państwie autorytarnym, jak i demokratycznym. Nie oznacza to jednak uniwersalizmu tego mechanizmu odnośnie do każdego ustroju. W każdych warunkach ustanowienie postępowań nakazowych i upominawczych uzasadniano chęcią przyspieszenia rozpoznania spraw ${ }^{1}$. Przyspieszenie zawsze wiązało się $\mathrm{w}$ tym przypadku $\mathrm{z}$ uproszczeniem, a z kolei drogą do uproszczanie było ograniczanie praw stron. Szczegółowe rozwiązania tworzące te postępowania różniły się w ciągu lat, ponieważ inne były możliwości uzasadnienia ograniczenia praw procesowych stron (głównie pozwanego). W demokratycznym państwie prawnym możliwości co do tego są szczególnie ograniczone, stąd niemała aktywność Trybunału Konstytucyjnego w przedmiotowym zakresie ${ }^{2}$.

${ }^{1} \mathrm{~W}$ doktrynie często określa się te postępowania mianem postępowań przyspieszonych (tak już w tytule książki S. Cieślak, Postępowania przyspieszone $w$ procesie cywilnym. Zarys postępowania nakazowego, upominawczego i uproszczonego, Warszawa 2004; ale też J. Cagara, Postępowanie nakazowe i upominawcze, NP 1971, nr 1, s. 87; S. Dalka, Ochrona sadowa roszczeń majątkowych $w$ postępowaniu nakazowym $i$ upominawczym, „Zeszyty Naukowe Wydziału Prawa i Administracji Uniwersytetu Gdańskiego. Prawo" 1977, nr 4, s. 23; B. Rozensztat, Postępowanie upominawcze, „Palestra” 1935, nr 1, s. 38; W. Siedlecki, Postępowanie cywilne w zarysie, Warszawa 1972 , s. 490.

2 Zob. między innymi sprawy dotyczące najnowszego z tego typu postępowań, czyli elektronicznego postępowania upominawczego: wyrok Trybunału Konstytucyjnego z dnia 13 marca 2012 r., P 39/10, Legalis 434353; wyrok Trybunału Konstytucyjnego z dnia 29 kwietnia 2020 r., P 19/16, Legalis 2333548; postanowienie Trybunału Konstytucyjnego z dnia 25 lutego 2020 r., Ts $127 / 18$, Legalis 2356588 . 
Nie bez znaczenia jest okoliczność, że w polskiej procedurze cywilnej znaczna liczba spraw sądowych rozpoznawana jest w postępowaniach opierających się na mechanizmie nakazowym ${ }^{3}$. W efekcie standardy co do praw procesowych w tych postępowaniach obrazują ich zachowanie w postępowaniu sądowym jako takim. Znamienne jest przy tym, że obecnie są aż cztery postępowania odrębne związane z tym mechanizmem. Pierwotnie, od 1930 roku, były tylko dwa postępowania: postępowanie nakazowe i postępowanie upominawcze ${ }^{4}$ (model tych postępowań zaczerpnięto z prawa austriackiego). Od 12 grudnia 2008 roku można dochodzić roszczeń w europejskim postępowaniu nakazowym ${ }^{5}$, a od 1 stycznia 2010 roku w elektronicznym postępowaniu upominawczym (wraz z pojawieniem się tego postępowania tradycyjne postępowanie upominawcze zwykło się potocznie nazywać „zwykłym” postępowaniem upominawczym dla odróżnienia od postępowania elektronicznego). Choć w każdym z tych postępowań wydaje się nakaz zapłaty, to inne są podstawy jego wydania. Nadmienić warto, że pierwotnie postępowania $\mathrm{z}$ mechanizmem nakazowym były jedynymi postępowaniami odrębnymi, dziś zaś są jedynie czterema z wielu.

\section{Organ wydający nakaz zapłaty}

Dopuszczalność mechanizmu nakazowego w postępowaniu cywilnym w świetle wymogów demokratycznych demokratycznego państwa prawnego uzależniona jest od konstrukcji poszczególnych elementów tworzących model tego mechanizmu. Istotne znaczenie ma organ rozstrzygający sprawy. $\mathrm{W}$ okresie obowiązywania obecnego kodeksu postępowania cywilnego ${ }^{6} \mathrm{w}$ czasie od 1 stycznia 1965 roku do 1 lipca 1985 roku mocą art. 480 k.p.c. (w ówczesnym brzmieniu) postępowanie nakazowe i upominawcze należało do zakresu działania

3 Przykładowo w 2018 r. wpłynęło do sądów powszechnych 9049,1 tys. spraw cywilnych (bez rodzinnych), w tym aż 3369,5 tys. to sprawy nakazowe i upominawcze (Główny Urząd Statystyczny, Rocznik Statystyczny Rzeczypospolitej Polskiej, Warszawa 2019, s. 165).

4 Rozporządzenie Prezydenta Rzeczypospolitej z dnia 29 listopada 1930 r. — Kodeks postępowania cywilnego (tekst jedn. Dz.U. z 1950 r. Nr 43, poz. 394 ze zm.). Kodeks ten często powołuje się w dacie wydania pierwszego tekstu jednolitego jako Kodeks postępowania cywilnego z $1932 \mathrm{r}$. (pierwszy tekst jedn. Dz.U. z 1932 r. Nr 112, poz. 934). W akcie z 1930 r. postępowanie nakazowe uregulowane było $w$ art. 465-475, a postępowanie upominawcze w art. 476-485. Natomiast w regulacji z 1932 r. odpowiednio w art. 458-468 i art. 469-478.

5 Postępowanie to, w odróżnieniu od pozostałych, zostało ustanowione na szczeblu prawa unijnego mocą rozporządzenia (WE) nr 1896/2006 Parlamentu Europejskiego i Rady z dnia 12 grudnia 2006 r. ustanawiające postępowanie w sprawie europejskiego nakazu zapłaty, Dz. Urz. UE L 399 z 30.12.2006, s. 1-32 (dalej: rozporządzenie 1896/2006).

${ }^{6}$ Ustawa z dnia 17 listopada 1964 r. Kodeks postępowania cywilnego, tekst jedn. Dz.U. z 2021 r. poz. 1805 ze zm. (dalej: k.p.c.). 
państwowych biur notarialnych ${ }^{7} \mathrm{z}$ wyjątkiem czynności zastrzeżonych dla sądów. Między rokiem 1985 i 1990 Minister Sprawiedliwości, mocą art. 480 § 2 zd. 1 k.p.c., mógł, rozporządzeniem, przekazać właściwym sądom czynności wykonywane w postępowaniu nakazowym i upominawczym przez państwowe biura notarialne. Od zaś 1 października 1990 roku postępowanie nakazowe i upominawcze należy do zakresu działania sądów.

W dalszych latach do wydawania nakazów zapłaty zostali uprawnieni referendarze sądowi. Zgodnie $z$ aktualnie obowiązującym art. $480^{4} \S 2$ k.p.c. czynności, z wyłączeniem prowadzenia rozprawy i wydania wyroku, może wykonywać referendarz sądowy. Zanim jednak referendarze uzyskali generalne umocowanie do wydania nakazów zapłaty, ich kompetencje były ograniczone do „zwykłego” postępowania upominawczego, elektronicznego postępowania upominawczym oraz europejskiego postępowania nakazowego. Ciekawym rozwiązaniem jest obecnie na gruncie elektronicznego postępowania upominawczego skomasowanie rozpoznania wszystkich spraw w jednym sądzie, czyli Sądzie Rejonowym Lublin-Zachód.

Choć w ramach zmian ustrojowych w końcu XX wieku sądy stały się wyłącznie uprawnione do rozpoznawania spraw w postępowaniu nakazowym i upominawczym, to nie było to niezbędne do realizacji zasady demokratycznego państwa prawnego. Dlatego nie budzi wątpliwości uprawnienie w kolejnych latach referendarzy do wydawania nakazów zapłaty. Nie można też wykluczyć dalszych zmian w przedmiotowym zakresie.

\section{Postępowanie dowodowe i doręczenia}

Kwestia organu wydającego nakazy zapłaty bezpośrednio koresponduje z problematyką doniosłości dowodów (czy inaczej ujmując — postępowania dowodowego) dla wydania nakazu zapłaty. Można byłoby oba te zagadnienia sprowadzić do twierdzenia, że jedynie sądy (ewentualnie referendarze) są właściwe do oceny dowodów. Do wydania nakazu zapłaty nie zawsze jednak konieczne jest przeprowadzania postępowania dowodowego, w szczególności na potrzeby wydania nakazu zapłaty w ,zwykłym” postępowaniu upominawczym i elektronicznym postępowaniu upominawczym. W tych ostatnich postępowaniach modelowo kwestia merytorycznej oceny dowodów (poza kwestiami wprost wskazanymi w art. $499 \S 1$ k.p.c., w którym mowa przy tym o „treści pozwu”) nie powinna

7 Zob. więcej S. Dalka, Postępowanie nakazowe i upominawcze w świetle nowelizacji k.p.c., „Rejent” 1997, nr 7-8, s. 136-137; a także idem, Efektywność postępowania nakazowego i upominawczego w procesie cywilny, „Palestra” 1978, nr 5-6, s. 29. Zgłaszane były postulaty powrotu do umocowania notariuszy do wydawania nakazów zapłaty (por. B. Tymecki, Notarialny nakaz zapłaty. Uwagi de lege ferenda do projektu OIRP/B-150, „Rejent” 2009, nr 10, s. 137-146; E. Marszałkowska-Krześ, Nakaz zapłaty wydawany przez notariusza, „Rejent” 2010, nr 3, s. 153-158). 
wpływać na nakaz zapłaty, ponieważ charakter prawny nakazu zapłaty wydanego w tych postępowaniach nie powinien wskazywać na (nawet wstępną) ocenę powództwa jako zasadnego w świetle materiału dowodowego.

Współcześnie mechanizm nakazowy należy przy tym postrzegać inaczej aniżeli dawniej za sprawą postępu komunikacyjnego, przez co należy rozumieć nie tylko rozwój kanałów komunikacji zwłaszcza elektronicznej, lecz także zwiększenie mobilności ludzi. Wydaje się, że problem doręczeń sądowych stał się w Polsce szczególnie problematyczny właśnie za sprawą mechanizmu nakazowego, a zwłaszcza wskutek funkcjonowania elektronicznego postępowania upominawczego. Sytuacja jest o tyle istotna, że wskutek wadliwego doręczenia może dojść do egzekucji roszczenia bez jakiejkolwiek wiedzy pozwanego o zakończonym postępowaniu rozpoznawczym. Doprowadziło to zresztą do istotnych zmian w zakresie tak zwanej fikcji doręczenia (art. $139^{1}$ k.p.c.), przy czym na potrzeby wspomnianego elektronicznego postępowania upominawczego przewidziano specjalne unormowanie (art. $505^{34} \S 1$ k.p.c.).

Kwestia doręczenia to przede wszystkim kryterium oceny efektywności i sprawności postępowania. Zasadniczo nie chodzi tu o różne możliwości doręczania, ponieważ sam sposób doręczenia jest kwestią wtórną w modelu mechanizmu nakazowego. Dla tego mechanizmu istotne jest jedynie, aby doręczenia były skuteczne w znacznej liczbie spraw. Jeżeli byłoby na odwrót, czyli doręczenia byłyby w znacznej liczbie spraw nieskuteczne, niezależnie nawet od tego, czy byłaby przyjmowana tak zwana fikcja doręczenia, to podważony zostałby sens wykorzystywania mechanizmu nakazowego, a nawet można uznać, że w takiej sytuacja wypaczona zostałby jego istota, którą jest swoiście rozumiana bezsporność ${ }^{8}$.

\section{Podsumowanie}

Mechanizm nakazowy w procesie cywilnym powinien uzupełniać rozpoznawanie spraw w postępowaniu zwyczajnym, ewentualnie w postępowaniach odrębnych wyróżnianych dla danego typu podmiotów. Jeżeli liczba spraw rozpoznawanych w mechanizmach nakazowych jest znacząca, to w gruncie rzeczy stają się one zasadniczym, gdyż przeważającym sposobem załatwiania spraw. Wówczas postępowanie zwyczajne, wbrew nazwie, miałoby charakter rozwiązania

8 W kwestii bezsporności zob. J. Bekerman, Postępowanie nakazowe i postępowanie upominawcze, „Gazeta Sądowa Warszawska” 1933, nr 5, s. 66; T. Ereciński, Postepowania odrębne de lege lata $i$ de lege ferenda, [w:] Ewolucja polskiego postepowania cywilnego wobec przemian politycznych, społecznych i gospodarczych, red. K. Flaga-Gieruszyńska, H. Dolecki, Warszawa 2008, s. 9, 11; M. Jędrzejewska, Zmiana istoty postępowań odrębnych $w$ sprawach prostych i drobnych, „Studia Iuridica” 36, 1998, s. 23; eadem, Modele postepowania w cywilnych sprawach „,drobnych i prostych” (model sadowy, arbitrażowy, administracyjny), „Palestra” 1977, nr 7, s. 18, 20; B. Rozensztat, Postepowanie upominawcze, „Palestra” 1935, nr 1, s. 38. 
wyjątkowego. Wyłania się tu kwestia dylematu między zapewnieniem efektywności wymiaru sprawiedliwości a respektowaniem gwarancji procesowych stron postępowania. Ten dylemat najczęściej rozstrzygany jest na płaszczyźnie wartości i jako taki nie może być oceniany na podstawie jednoznacznych kryteriów. Inaczej jest w wykorzystywaniu mechanizmu nakazowego. W zakreślonym aspekcie istotne jest porównanie liczby spraw rozpoznawanych w tym i innych postępowaniach.

Trzeba mieć na względzie, że mimo wspomnianej wiekowej historii mechanizmu nakazowego nie jest on postrzegany jako rozwiązanie, które miałoby zostać zastąpione przez inne (nowocześniejsze) mechanizmy. Przeciwnie, odwołanie się do tego mechanizmu przez prawodawcę europejskiego (ustanowieniem na szczeblu prawa Unii Europejskiej postępowania w sprawie europejskiego nakazu zapłaty, zwanego w prawie polskim europejskim postępowaniem nakazowym) spowodowało, że mechanizm ten (w postaci relatywnie bliskiej polskim rozwiązaniom, co nie znaczy, że na polskich uregulowaniach wzorowanym) upowszechnił się w państwach członkowskich Unii Europejskiej, a jednocześnie, jak można przypuszczać, na stałe został adaptowany do porządków prawnych poszczególnych państw.

Wreszcie, to właśnie w mechanizmie nakazowym tkwi potencjał do pogłębionej informatyzacji postępowania cywilnego przez jego zautomatyzowanie, czemu też dał wyraz prawodawca unijny, stwarzając państwom członkowskim Unii Europejskiej stosowne możliwości w tym zakresie. Przepis art. 8 zd. 2 rozporządzenia 1896/2006 mianowicie umożliwia wykorzystanie zautomatyzowanej procedury badania pozwu. W wypadku prawa polskiego doszło zresztą do wykorzystania mechanizmu nakazowego $\mathrm{w}$ ramach kompleksowo zinformatyzowanego postępowania, jakim jest elektroniczne postępowanie upominawcze. Warto dodać, że S. Dalka ${ }^{9}$ już w latach siedemdziesiątych XX wieku zasygnalizował możliwość rozważania wykorzystania komputerów do wydawania nakazów zapłaty.

\section{Bibliografia}

Bekerman J., Postępowanie nakazowe i postępowanie upominawcze, „Gazeta Sądowa Warszawska” 1933, nr 5, s. 65-67.

Cagara J., Postępowanie nakazowe i upominawcze, „Nowe Prawo” 1971, nr 1, s. 86-106.

Cieślak S., Postępowania przyspieszone w procesie cywilnym. Zarys postępowania nakazowego, upominawczego i uproszczonego, Warszawa 2004.

Dalka S., Efektywność postępowania nakazowego i upominawczego w procesie cywilny, „Palestra” 1978, nr 5-6, s. 21-30.

Dalka S., Ochrona sądowa roszczeń majątkowych w postepowaniu nakazowym i upominawczym, „Zeszyty Naukowe Wydziału Prawa i Administracji Uniwersytetu Gdańskiego. Prawo” 1977, nr 4.

9 S. Dalka, Ochrona sądowa roszczeń..., s. 289. 
Dalka S., Postępowanie nakazowe i upominawcze w świetle nowelizacji k.p.c., „Rejent” 1997, nr 7-8, s. 135-148.

Ewolucja polskiego postępowania cywilnego wobec przemian politycznych, społecznych i gospodarczych, red. K. Flaga-Gieruszyńska, H. Dolecki, Warszawa 2008.

Jędrzejewska M., Modele postępowania w cywilnych sprawach „,drobnych i prostych” (model sąowy, arbitrażowy, administracyjny), „Palestra” 1977, nr 7, s. 14-25.

Jędrzejewska M., Zmiana istoty postępowań odrębnych $w$ sprawach prostych $i$ drobnych, „Studia Iuridica” 36, 1998, s. 21-28.

Marszałkowska-Krześ E., Nakaz zapłaty wydawany przez notariusza, „Rejent” 2010, nr 3, s. 153-158.

Rozensztat B., Postępowanie upominawcze, „Palestra” 1935, nr 1, s. 38-42.

Siedlecki W., Postępowanie cywilne w zarysie, Warszawa 1972.

System prawa procesowego cywilnego, red. W. Berutowicz, t. 2, Wrocław 1987.

Tymecki B., Notarialny nakaz zapłaty. Uwagi de lege ferenda do projektu OIRP/B-150, „Rejent” 2009, nr 10, s. 137-146. 